\title{
Brood care in Brachyuran crabs: the effect of oxygen provision on reproductive costs
}

\author{
Cuidado maternal en crustáceos braquiuros: el efecto de la provisión de oxígeno sobre \\ los costos de la reproducción
}

MIRIAM FERNÁNDEZ ${ }^{1} \&$ ANTONIO BRANTE ${ }^{2}$

\begin{abstract}
Estación Costera de Investigaciones Marinas and Center for Advanced Studies in Ecology \& Biodiversity, Facultad de Ciencias Biológicas, Pontificia Universidad Católica de Chile, Casilla 114-D, Santiago, Chile; e-mail: mfernand@genes.bio.puc.cl ${ }^{1}$, abrante@genes.bio.puc.cl ${ }^{2}$
\end{abstract}

\begin{abstract}
The quantification of the costs associated with parental care of marine invertebrates requires a first and necessary step, which is the identification of the different forms of care exhibited by this group. Among marine invertebrates, provision of oxygen to the aggregation of embryos may be critical, although most evidence on the link between oxygen limitation and parental care is indirect. Species which show active behavior directed at providing oxygen to the brood offer a good model to establish the direct link between behavioural patterns and oxygen provision to the embryos, and to estimate the costs associated with this form of care. In this manuscript, we conducted a review of the current knowledge about oxygen limitation in embryos aggregations of marine invertebrates in general and Brachyuran crabs in particular. Most of the emphasis focuses on recent results on Brachyuran crabs and new information on Ovalipes trimaculatus. The consequences of oxygen limitation on investment in reproduction and clutch size determination are analyzed. Temporal patterns of oxygen availability in the center of embryo masses of Brachyuran crabs are different from other brooding species of marine invertebrates. A cyclic pattern in oxygen partial pressure $\left(\mathrm{PO}_{2}\right)$ was detected in masses of early stage embryos, and constant, high $\mathrm{PO}_{2}$ in females carrying late stage embryos, for all crab species studied so far. As changes in $\mathrm{PO}_{2}$ in the embryo mass occurred, an increase in oxygen demand by the embryos and an increase in abdominal flapping frequency were detected in all species. Moreover, the rate of increase in the frequency of abdominal flapping between females carrying early and late stage embryos varied among species, depending on oxygen consumption rate of the embryos. In spite of this, embryos of all species experience similar oxygen conditions throughout development. Abdominal flapping seems to be the main behavior used to provide oxygen to the embryos, regardless of the habitat types inhabited by brooding females. Recent studies have shown that ovigerous female crabs consume a substantially higher amount of oxygen than non-brooding females, and suggested that there may be a trade-off between investment in eggs and in ventilation of the embryos. This information supports the need for including the cost of oxygen provision in the estimation of maternal effort. A broad range of possible areas of research are proposed to advance in this direction, concentrating either on marine invertebrates in general, or Brachyuran crabs in particular.
\end{abstract}

Key words: reproduction, brood care, crabs, oxygen, marine invertebrates.

\section{RESUMEN}

La cuantificación de los costos asociados con cuidado parental en invertebrados marinos requiere de un primer paso, muy necesario, cual es la identificación de los diferentes tipos de cuidado parental presentes en este grupo. Entre los invertebrados marinos, la provisión de oxígeno a las agregaciones de embriones es crítica, pero hasta ahora las evidencias que ligan el cuidado maternal con la provisión de oxígeno son indirectas. Las especies que muestran comportamientos activos dirigidos a la provisión de oxígeno a los embriones ofrecen un buen modelo de estudio para establecer la relación entre cuidado maternal y provisión de oxígeno, permitiendo además estimar los costos asociados. En este manuscrito, presentamos una revisión de la información existente sobre limitación de oxígeno en agregaciones de embriones de invertebrados marinos en general, y de braquiuros en particular. El principal énfasis es en resultados recientes sobre Braquiuros y nueva información sobre Ovalipes trimaculatus. Las consecuencias de la limitación de oxígeno sobre inversión en reproducción y determinación del tamaño de la camada son analizadas. Los patrones temporales de disponibilidad de oxígeno en el centro de masas de embriones de Braquiuros difiere de otras especies de invertebrados marinos. Un patrón cíclico de presión parcial de oxígeno $\left(\mathrm{PO}_{2}\right)$ se observa en masas de embriones tempranos, mientras que niveles altos y constantes de $\mathrm{PO}_{2}$ se han encontrado en hembras con embriones en estadíos tardíos de desarrollo. A medida que ocurren estos cambios en $\mathrm{PO}_{2}$ en la masa de embriones, se detectó un aumento en el consumo de oxígeno de los embriones y en la frecuencia del batido abdominal de las hembras. Este patrón también se pudo observar al comparar la frecuencia del batido abdominal entre especies que muestran diferentes tasas de consumo de sus embriones. A pesar de estas diferencias, los embriones de todas las especies experimentan bajos niveles 
de $\mathrm{PO}_{2}$ durante fases tempranas del desarrollo y altos niveles de $\mathrm{PO}_{2}$ en estadíos tardíos. En todas las especies el batido abdominal parece ser el principal comportamiento utilizado para proveer oxígeno a los embriones, independientemente del tipo de hábitat utilizado por los adultos. Estudios recientes han mostrado que hembras ovígeras de braquiuros consumen significativamente más oxígeno que las hembras no ovígeras, y sugieren que hay un compromiso entre inversión en huevos e inversión en ventilar esos embriones. Estas evidencias muestran la necesidad de incluir el costo de provisión de oxígeno en la estimación del esfuerzo maternal. Se presenta un amplio rango de posibles líneas de interés para investigar este problema y avanzar en nuestro conocimiento, utilizando como modelos invertebrados marinos en general, y los braquiuros en particular.

Palabras clave: reproducción, cuidado maternal, cangrejos, oxígeno, invertebrados marinos.

\section{INTRODUCTION}

In spite of the difficulties in determining the costs and benefits of parental care, there is no doubt that parental care has a cost and produces large benefits, and that both factors have important implications in shaping life history patterns of terrestrial invertebrates (e.g., Wilson 1971, Zeh \& Smith 1985), reptiles (e.g., Shine 1988), birds (e.g., Lack 1968, Brown 1987), and mammals (e.g., Clutton-Brock et al.1981). Studies on parental care of marine invertebrates are rare and the few available have focused more on the benefits to the offspring than on the cost to the parents (see Diesel 1989, 1992a, 1992b, Thiel 1999a, 1999b). The quantification of the costs associated with parental care of marine invertebrates requires a first and necessary step, which is the identification of the forms of care exhibited by this group. Although some forms of parental care may be common to both marine and terrestrial systems (e.g., protection from predators, provision of food), others may differ, considering the differences between both environments. The identification of the factors that affect the degree of parental care and effort is critical to advance our understanding of life history patterns at sea.

In a broad sense, parental care includes the generation of environmental conditions for egg and offspring development. Among marine invertebrates, provision of oxygen to the aggregation of embryos may be critical to generate the proper environmental conditions for development, since several studies have shown that oxygen is a limiting factor during embryo development (Chaffee \& Strathmann 1984, Booth 1995, Cohen \& Strathmann 1996, Lardies \& Fernández 2002). It is interesting to point out that different taxa of marine invertebrates share the same diversity of modes of development, so a single and common factor, such as oxygen limitation in embryo aggregations, could affect the capacity of most groups to brood. In fact, it has been proposed that broadcasting of eggs, a strategy observed in most taxa of marine invertebrates, may be an easy and inexpensive way to provide oxygen to a large numbers of embryos (Strathmann \& Chaffee
1984). However, the solutions to the problem of oxygen provision in brooding species do not seem to be uniform across taxa. For instance, some brooding species seem to provide extra-embryonic material to the embryo aggregations to help passive oxygen diffusion (Strathmann \& Strathmann 1995, Lee \& Strathmann 1998) while other species show active behavior directed at providing oxygen to the brood (Fernández et al. 2000, Baeza \& Fernández 2002). Most evidence on the link between oxygen limitation and maternal care among marine invertebrates is indirect, as they come from taxa which aggregate embryos in gelatinous masses or encapsulate embryos (Strathmann \& Strathmann 1995, Lee \& Strathmann 1998). However, brooding species which exhibit active behavior directed at providing oxygen to the brood offer a good model to establish the direct link between behavioural patterns and oxygen provision to the embryos, and to estimate the costs associated with this form of parental care. Since in most cases brood care is provided by females, we will refer to oxygen provision as maternal care from now on.

A comprehensive analysis of the few pieces of evidence linking oxygen provision to the embryos and maternal care to further understand the apparently consistent problem of oxygen limitation during early development across taxa of marine invertebrates, and its effect on investment in reproduction and clutch size determination, has not yet been conducted. However, this simple physiological constraint on brood care may have important ecological and evolutionary consequences (Strathmann \& Chaffee 1984). In this manuscript, an overview of the current knowledge about oxygen limitation in embryo aggregations of marine invertebrates is presented and the consequences on investment in reproduction and clutch size determination are analyzed. New information on oxygen provision and maternal care in a crab species which does no bury while brooding is also presented, since existing information is based exclusively on species which do not bury during the brooding period. The main emphasis is on Brachyuran crabs because: (1) several species of Brachyuran crabs are among the largest brood- 
ers in nature, (2) investment in eggs is well studied, (3) behaviors associated to brooding are obvious and recently the link between those behaviors and oxygen provision has been shown, and (4) the costs associated with oxygen provision have recently been estimated for several species and temperatures. The manuscript highlights a key aspect shaping life history strategies, such as cost of parental care, well studied in many animal taxa but virtually ignored in marine invertebrates.

\section{METHODOLOGICAL APPROACHES}

Two types of information were used to meet the goals proposed. First, existing information on oxygen limitation during early development in marine invertebrates in general, and Brachyuran crabs in particular, was compiled. This information was used to draw general conclusions on oxygen limitation in embryo mass aggregations and to analyze its consequences on investment in reproduction. Second, new information on Ovalipes trimaculatus is presented and compared with published information on other crab species. The results for $O$. trimaculatus are important because it is unclear if the main behavior linked to oxygen provision in other crab species (abdominal flapping; Fernández et al. 2000, Baeza \& Fernández 2002, Ruiz-Tagle et al. 2002) can be performed if ovigerous females bury themselves. Thus, the identification of alternative methods of oxygen provision, and the associated costs, is important.

Patterns of female behavior during the brooding period, patterns of oxygen provision to the embryos, and the costs of oxygen provision were studied in females of $O$. trimaculatus carrying early and late stage embryos. Embryo stage in experimental females was determined by removing few embryos from the periphery of the embryo mass, and staging the embryos under the stereomicroscope (early stage: gastrulation, some cell without vitellium of the animal pole; late stage: heart pumping, ocular pigment and chromatophores present). All experiments were conducted at constant temperature $\left(14^{\circ} \mathrm{C}\right)$ and calibration of the instruments for oxygen measurements were done using a solution saturated with $(\mathrm{Na})_{2} \mathrm{SO}_{3}(0 \%$ air saturation) and aerated water ( $100 \%$ air saturation). The same methodological approach described by Baeza \& Fernández (2002) was used.

In order to determine patterns of female behavior during the brooding period, female crabs were placed individually in a 16-1 transparent plastic tank filled with a $10-\mathrm{cm}$ layer of sand and aerated sea water. The behavior of each female was vid- eotaped continuously over a 12 -h period (night) using a Sony (time-lapse) video recorder and a Pelco vigilance camera, starting two hours after the crab was introduced to the tank. After identifying the behaviors exhibited by brooding females, the following behaviors were recorded: abdominal flapping, maxilliped beating, and pereiopod probing. These behaviors were also identified in other crab species (Baeza \& Fernández 2002). A total of four non-brooding females and four brooding females for each embryo stage were measured. Oxygen partial pressure in the center of the embryo mass was recorded simultaneously, using optic fibers (microoptode). In this case, only brooding females were used. The microoptode was placed in the center of the embryo mass by drilling a small hole through the sixth abdominal segment of each brooding female. The tip of the microoptode was placed in the center of the brood mass after passing it through the tube, and then the optode was glued in place (see Baeza \& Fernández 2002). Oxygen partial pressure (percentage of air saturation) was recorded on a computer every 5 seconds during the 12-h experiment. The microoptode does not have any effect on female behavior (Baeza \& Fernández 2002, Ruiz-Tagle et al. 2002).

Correlations between the duration of specific behaviors and the difference in oxygen availability (percentage of air saturation) in the brood mass, recorded immediately before and right after each specific behavior was performed, were examined. A positive correlation suggests that the behavior may be used to provide oxygen to the embryo mass (Baeza \& Fernández 2002). The behavior of non-brooding females was included only when performed at least once by these females. Given that no abdominal flapping and pereiopod probing were observed in non-brooding crabs (see below), the proportion of time that both behaviors were performed during the recording time were compared between brooding females carrying early and late stage embryos using a Student t-test. An ANOVA test was used to compare maxilliped beating of non-brooding and brooding females (carrying embryos at different developmental stages). A SNK test was performed for a posteriori comparisons. Finally, the percentage of time that low oxygen partial pressure (< $10 \%$ air saturation) was recorded during the experimental period in the center of the embryo mass was compared between females carrying early and late stage embryos, using a ttest. This analysis allowed us to determine the effect of changes in female behavior on oxygen conditions in the embryo mass throughout the brooding season. 
In order to test whether female behaviour associated with oxygen provision (brood care) represented a cost for the brooding females, oxygen consumption of non-brooding (embryos removed) and brooding females carrying early and late stage embryos was measured (12 non-brooding females and six brooding females for each embryo stage). In order to estimate oxygen consumption of brooding females, we subtracted the consumption of the embryo mass. Then, the difference in the metabolic rate between brooding and non-brooding females was assumed to be the cost of oxygen provision (part of the cost of brooding). Closed respiration chambers (11-1) were used, and oxygen depletion (between 100 and $70 \%$ air saturation) was monitored continuously with oxygen electrodes (see Baeza \& Fernández 2002 for further details). Oxygen consumption of the embryo mass was obtained as the product of the weight of the embryo mass and the rate of oxygen consumption of embryos per gram at the same developmental stage. To estimate oxygen consumption of the embryos, a small numbers of embryos (30-40) were removed from brooding females and were immediately placed on a fine grid in a double wall, closed microchamber, filled with $2 \mathrm{~mL}$ of stirred, filtered $(0.2 \mu \mathrm{m})$ sea water and added antibiotic $(20 \mu \mathrm{L}$ with $5 \mathrm{mg} \mathrm{mL}^{-1}$ of Penicillin and $5 \mathrm{mg} \mathrm{mL}^{-1}$ of Amoxicillin). After calibration (see above), the rate of oxygen depletion was recorded. During measurements, a stir bar under the grid was used to mix water and homogenize oxygen partial pressure inside the chamber. The grid avoids direct contact between the stir bar and the embryos, which could produce some disturbance (Naylor et al. 1999). Oxygen consumption of the embryos was measured at $\mathrm{PO}_{2}$ between 70 and $100 \%$. These levels of $\mathrm{PO}_{2}$ are higher than those experienced by early stage embryos, but are the normal conditions in the embryo masses of females carrying late stage embryos. Thus, oxygen consumption of brooding females carrying early stage embryos will be underestimated and our conclusions will be conservative. Oxygen consumption per unit of time and wet weight of non-brooding and brooding females was compared using a one-way ANOVA.

\section{PATTERNS OF OXYGEN AVAILABILITY IN EMBRYO AGGREGATIONS OF MARINE INVERTEBRATES}

Oxygen availability in the center of the embryo mass of several marine invertebrate species, belonging to different taxa, is clearly lower than in the periphery, or than in the surrounding seawater (intertidal gastropods: Booth 1995, Cohen \& Strathmann 1996, Lardies \& Fernández 2002; polychaetes: Cohen \& Strathmann 1996; artificial gelatinous embryo masses: Strathmann \& Strathmann 1995, Lee \& Strathmann 1998; crabs: Naylor et al. 1999, Fernández et al. 2000, 2003). Oxygen limitation has also been suggested by other authors (Crisp 1959, Perron \& Corpuz 1982). The characteristics of the aggregations where oxygen availability has been determined vary from packed embryos masses (crabs) to masses with embryos interspaced by the presence of gel (gastropods, polychaetes). Two contrasting temporal patterns of oxygen availability in the center of embryo masses of marine invertebrates emerged from the studies on these two types of aggregations, the first occurring over a very short temporal scales (minutes to hours) and the second occurring throughout the whole developmental period: (1) Small temporal scale variations: although the information on shortterm fluctuations in oxygen availability is limited, contrasting temporal patterns of oxygen availability have been found between Brachyuran crabs and gelatinous embryo masses. Oxygen availability in the center of aggregations of early stage embryos varies dramatically (from anoxia to normoxia) within minutes in Brachyuran crabs (Fernández et al. 2000, Baeza \& Fernández 2002) while in gelatinous embryo masses oxygen fluctuates between day and night (Cohen \& Strathmann 1996). (2) Variations occurring throughout embryo development: gelatinous embryo masses and embryo cases showed a strong gradient in oxygen availability between the periphery and the center, and this gradient becomes stronger as embryo development progresses (Chaffee \& Strathmann 1984, Booth 1995, Cohen \& Strathmann 1996, Lardies \& Fernández 2002). In contrast, the gradient in oxygen availability between the periphery and the center of the embryo mass of Brachyuran crabs decreases throughout development, in spite of the increase in oxygen demand of the embryos (Naylor et al. 1999, Baeza \& Fernández 2002).

In gelatinous embryo masses, limited oxygen diffusion, embryo oxygen consumption, oxygen consumption and production by algae associated with the embryo mass, and spacing among embryos seem to determine the temporal patterns found. Oxygen consumption and production by algae associated with the embryo mass seem to explain the daily patterns of variation within gelatinous embryo mass (Cohen \& Strathmann 1996). Spacing among embryos, determined by embryo size and the presence of gel, affects both shortterm and developmental patterns of oxygen gradients. Stronger oxygen gradients between the periphery and the center in gelatinous embryo masses throughout development can be explained simply by the increase in oxygen consumption of the 
embryos and limited oxygen diffusion. The same explanation does not hold for Brachyuran crabs, since oxygen availability in the center of the embryo mass increases as oxygen consumption of the embryos increases during embryo development (Booth 1995, Baeza \& Fernández 2002). This, in spite the fact that Brachyuran crabs present the worst case for passive oxygen diffusion. Oxygen diffusion seems to be facilitated by increasing the interstitial pores between embryos, which allow the flow of oxygenated water to the embryos, or by the presence of gel which increases the spacing among embryos, enhancing the delivery of oxygen (Lee \& Strathmann 1998). Brachyuran crabs exhibit highly packed embryo masses, no gel, and in some species relatively small embryos. Thus, the main cause of the differences in temporal variations in oxygen availability between gelatinous and crab embryo masses seems to be maternal ventilation of the embryo mass. In Brachyuran crabs, females change their behavior during the brooding period, increasing the frequency of abdominal flapping throughout embryo development (Baeza \& Fernández 2002). Recent studies have shown that abdominal flapping is the main behavior that helps to provide oxygen to the embryos (Baeza \& Fernández 2002, Ruiz-Tagle et al. 2002), and suggested that female crabs accommodate oxygen provision according to the embryos needs. Moreover, the short-term fluctuation in oxygen availability in the center of the embryo mass of Brachyuran crabs during early development seems to be the result of the combination between female behavior and embryo oxygen consumption (Fernández et al. 2000). Basically, the contrasting patterns observed in embryo aggregations seem to be related to the type of solution used by the different groups to generate the environmental conditions appropriate for embryo development.

The differences in oxygen availability between the center and the periphery of embryo masses of passive oxygen providers seem to affect embryo development, since a delay in inner embryo development has been found in gelatinous embryo masses (Chaffee \& Strathmann 1984, Strathmann \& Strathmann 1995). Moreover, the delay becomes greater as embryos develop. This delay in development can be explained by lower oxygen consumption rates of embryos at low oxygen partial pressures, which affect developmental rate (Patel \& Crisp 1960, Weathly 1981, Booth 1995 , Naylor et al. 1997, Fernández et al. 2000). Embryos of Brachyuran crabs do not seem to suffer low oxygen levels during late development (Naylor et al. 1999, Fernández et al. 2000), probably because the change in female patterns of oxygen supply throughout development compensates the higher oxygen de- mand of late stage embryos (Fernández et al. 2003). However, during early development dramatic differences in oxygen availability between the center and the periphery of the embryo masses have been found in several crab species (Naylor et al. 1999, Fernández et al. 2000). This limitation in oxygen during early development may cause the small delay in development found in Brachyuran crabs (Fernández et al. 2003). It is important to note that while a $20 \%$ difference in embryo size between embryos from the periphery and the center has been reported for the polychaete Nereis vexillosa (Chaffee \& Strathmann 1984), only a $2 \%$ difference was found in two species of Brachyuran crabs (Cancer setosus and Homalaspis plana, Fernández et al. 2003). Since embryo size of marine invertebrates increases throughout development, differences in embryo size can be related to differences in development. Similar results have been reported for other indicators of development (e.g., stage, yolk, oxygen consumption of the embryos). For instance, a delay of three stages of development has been reported in globose, gelatinous embryo masses, while only a $10 \%$ difference in yolk consumption between inner and outer embryos was found in Brachyuran crabs (Chaffee \& Strathmann 1984, Fernández et al. 2003). It is interesting to note that inner embryos of Brachyuran crabs consume oxygen at a lower rate than outer embryos at any given $\mathrm{PO}_{2}$ level, which could be another sign of delayed development of inner embryos (Fernández et al. 2003). Severely retarded development was also found in embryos incubated in artificial embryo masses and this has been attributed to oxygen limitation (Strathmann \& Strathmann 1995).

A consistent pattern of retarded development of inner embryos, regardless of the mechanism used to supply oxygen into the embryo aggregation has been observed. However, patterns of inner and outer embryo development suggest that active oxygen provision performed by female crabs may be more efficient in supplying oxygen to the embryos than other passive ways of helping oxygen diffusion to the center of the embryo mass, such as gel.

\section{ACTIVE OXYGEN PROVISION TO THE EMBRYOS: THE CASE OF BRACHYURAN CRABS}

Patterns of oxygen availability and female behavior in Ovalipes trimaculatus

Oxygen availability (oxygen partial pressure) in the center of the embryo mass of $O$. trimaculatus showed a cyclic pattern during the early develop- 
ment of the embryos (Fig. 1). Early stage embryos spent significantly more time at low $\mathrm{PO}_{2}$ than embryos at late stage (Student t-test, $\mathrm{t}=-10.06$, df $=6, \mathrm{P}<0.001)$. Females carrying late stage embryos showed high oxygen partial pressure in the center of the embryo mass (Fig. 1).
The peaks of oxygen availability in the center of embryo masses of $O$. trimaculatus were associated with abdominal flapping, which were performed after females adopted the standing position. Abdominal flapping was the only behavior positively correlated with increases in oxygen

\section{Cancer setosus}

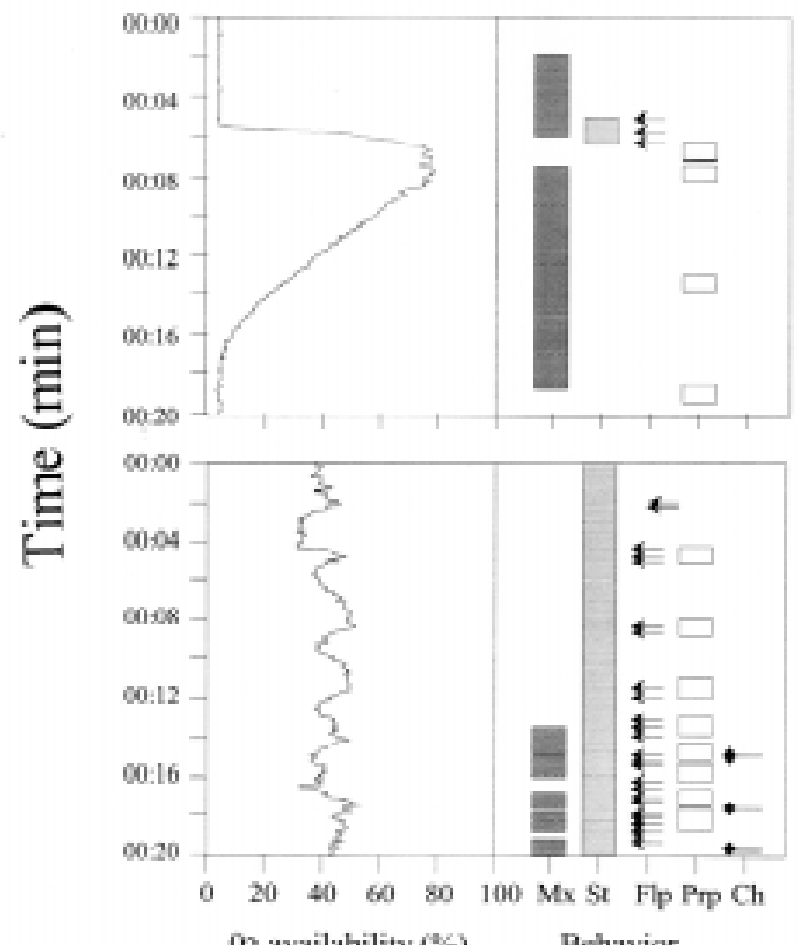

Ovalipes trimaculatus

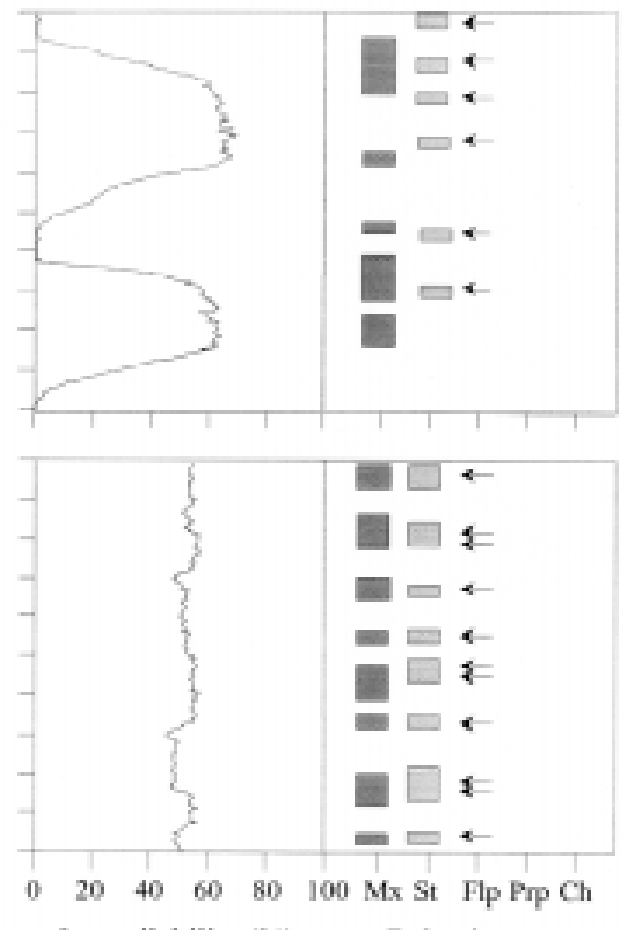

Fig. 1: Oxygen availability (\% air saturation) measured in the centre of the brood mass (left side of each graph) and timing of behaviours recorded simultaneously for a single brooding female (right side of each graph) over a period of $20 \mathrm{~min}$ in the laboratory. Each graph shows oxygen availability and behaviour of one female carrying embryos at early (top) and late (bottom) developmental stages. Behaviors are: $\mathrm{Mx}=$ maxilliped beating; $\mathrm{St}=$ standing; $\mathrm{Flp}=$ abdominal flapping; $\mathrm{Prp}=$ pereiopod probing; $\mathrm{Ch}=$ chela probing. Graphs on the left side are for Cancer setosus, and on the right side for Ovalipes trimaculatus. Arrows represent behavioral events that lasted less than $1 \mathrm{~min}$ and bars illustrate behaviors of relatively long duration (more than $1 \mathrm{~min}$ ). Each arrow indicates one behavioral event. The bars show the time interval of each long-duration behavior. The results shown here are for one female of each species and embryo developmental stage, but the patterns reported were consistent across replicates. The summary of the information for all females analyzed is shown in Table 1.

Disponibilidad de oxígeno (\% saturación) en el centro de la masa de embriones (lado izquierdo de cada cuadro) y registro simultáneo de los comportamientos observados en una hembra ovígera (lado derecho de cada cuadro), medidos en laboratorio en un período de $20 \mathrm{~min}$. Cada cuadro muestra la disponibilidad de oxígeno y comportamiento de una hembra incubando embriones tempranos (cuadros superiores de la figura) y tardíos (cuadros inferiores). Los comportamientos registrados fueron: $\mathrm{Mx}=$ batido de los maxilípedos, $\mathrm{St}=$ levantamiento del cuerpo por pereiópodos, Flp = batido del abdomen, Prp = introducción de pereiópodos en la masa de embriones $\mathrm{Ch}=$ introducción de la quela en la masa de embriones. Los cuadros del lado izquierdo corresponden a Cancer setosus y los del lado derecho a Ovalipes trimaculatus. Las flechas representan comportamientos de corta duración (menos de $1 \mathrm{~min}$ ) mientras que las barras ilustran comportamientos de larga duración (más de $1 \mathrm{~min}$ ). Cada flecha indica la realización de un evento conductual. Las barras muestran el tiempo asignado a cada comportamiento de larga duración. Los resultados que se muestran en esta figura son para una sola hembra de cada especie y estadío de desarrollo, pero los patrones son consistentes entre hembras. Resultados que incluyen todas las réplicas se muestran en Tabla 1. 
availability in the embryo mass (Kendall rank correlation, $\phi=0.6, \mathrm{n}=30, \mathrm{P}<0.001)$. No significant correlations were found between changes in oxygen availability and maxilliped beating (Kendall rank correlation, $\phi=0.005, \mathrm{n}=$ $30, \mathrm{P}>0.1)$, nor bewteen changes in oxygen availability and pereiopod probing (Kendall rank correlation, $\phi=0.17, \mathrm{n}=30, \mathrm{P}>0.1)$. The frequency of abdominal flapping was significantly higher in females carrying late stage embryos than in females carrying early stage embryos (Student t-test, $\mathrm{t}=-4.6, \mathrm{df}=6, \mathrm{P}<0.01$ ). The percentage of time at which pereiopod probing was performed did not show differences between females incubating early and late stage embryos (periopod probing: Student t-test $=0.69, \mathrm{df}=6, \mathrm{P}$ $>0.1$ ). Maxilliped beating was the only behaviour observed in non-brooding females, but it was exhibited at a lower frequency than in ovigerous females (one-way analysis of variance, $\mathrm{F}_{2,9}=4.84$, $\mathrm{P}>0.05$; Student-Newman-Keuls test: non-brooding < early stage $=$ late stage) .
Oxygen consumption of late stage embryos $\left(0.085 \pm 0.009 \mu \mathrm{mol} \mathrm{O} \mathrm{O}_{2} \mathrm{~min}^{-1} \mathrm{~g}^{-1}\right)$ was significantly higher than oxygen consumption of early stage embryos $\left(0.067 \pm 0.001 \mu \mathrm{mol} \mathrm{O} \mathrm{min}^{-1} \mathrm{~g}^{-1}\right.$; Mann-Whitney U test, $\mathrm{Z}=-2.6, \mathrm{n}=5, \mathrm{P}<0.01$ ), showing a $27 \%$ increase throughout development. Oxygen consumption of brooding and nonbrooding females increased significantly between non-brooding females and females carrying early stage embryos (50\% increase), and between females carrying early and late stage embryos (43 $\%$ increase, Table 1, one-way analysis of variance, $\mathrm{F}_{2,21}=37.1, \mathrm{P}<0.001$; a-posteriori comparisons: $\mathrm{P}$ values were always $<0.05)$.

\section{Review of existing information}

The patterns of oxygen provision to the embryos and female behavior are very consistent among species, suggesting that there is a common solution to the common problem of supplying oxygen

TABLE 1

Different variables related to egg production and embryo ventilation are shown for seven crab species. For each species, reproductive output (RO, ratio between dry weight of the embryo mass and female dry weight), oxygen consumption of late stage embryos, oxygen consumption of non-brooding females and brooding females carrying late stage embryos, percentage of time spent flapping the abdomen in females carrying late stage embryos, and oxygen condition in the embryo mass are reported. The increase in oxygen consumption between non-brooding and brooding females is also shown. Oxygen consumption is reported in $\mu$ mol $\mathrm{O}_{2} \mathrm{~min}^{-1} \mathrm{~g}^{-1}$. Oxygen condition in the embryo mass is shown as the percentage of time at oxygen partial pressures lower than $10 \%$. Data are not available are indicated as NA. Numbers between parentheses indicate standard error. Sources are Baeza \& Fernández (2002) and Fernández \& Pörtner (unpublished results)

Variables relacionadas a la producción de huevos y ventilación de los embriones en siete especies de jaibas. Para cada especie se reporta la inversión en huevos ( $\mathrm{RO}$, proporción entre peso seco de la masa de huevos y peso seco de la hembra), consumo de oxígeno de embriones en estado de desarrollo tardío, consumo de oxígeno de hembras no ovígeras y hembras ovígeras incubando embriones en estadíos tardíos de desarrollo, porcentaje de tiempo invertido en el batido del abdomen por hembras con huevos en estadíos tardíos, y condición de oxígeno en la masa de embriones. Esta última fue calculada como el porcentaje de tiempo en el cual la presión parcial de oxígeno disminuyó a menos del $10 \%$. El aumento en el consumo de oxígeno entre hembras no ovígeras y hembras portando huevos tardíos también se reporta. La unidad de consumo de oxígeno en todos los casos es $\mu$ mol $\mathrm{O}_{2} \mathrm{~min}^{-1} \mathrm{~g}^{-1}$. Los datos no disponibles se indican como NA. Números entre paréntesis indican el error estándar. Las fuentes son Baeza \& Fernández (2002) y Fernández \& Pörtner (resultados no publicados)

\begin{tabular}{|c|c|c|c|c|c|c|c|c|}
\hline \multirow[t]{2}{*}{ Species } & \multirow[t]{2}{*}{ R0 } & \multirow{2}{*}{$\begin{array}{l}\text { Oxygen } \\
\text { consumption } \\
\text { of the } \\
\text { embryos }\end{array}$} & \multirow{2}{*}{$\begin{array}{c}\text { Oxygen } \\
\text { consumption } \\
\text { of non-brooding } \\
\text { females }\end{array}$} & \multirow{2}{*}{$\begin{array}{l}\text { Oxygen } \\
\text { consumption } \\
\text { of brooding } \\
\text { females }\end{array}$} & \multirow{2}{*}{$\begin{array}{l}\text { Increase } \\
\text { in oxygen } \\
\text { consumption } \\
\text { of females }(\%)\end{array}$} & \multirow{2}{*}{$\begin{array}{l}\text { Percentage } \\
\text { of time spent } \\
\text { flapping the } \\
\text { abdomen }\end{array}$} & \multicolumn{2}{|c|}{$\begin{array}{l}\text { Oxygen condition in } \\
\text { in the embryo mass } \\
\left(\% \text { time at low } \mathrm{PO}_{2}\right)\end{array}$} \\
\hline & & & & & & & Early & Late \\
\hline Cancer pagurus $(170 \mathrm{~mm})$ & $0.098(0.007)$ & $0.67(0.008)$ & $0.05(0.009)$ & NA & $\mathrm{NA}$ & $\mathrm{NA}$ & $55(3.5)$ & 0 \\
\hline Cancer setosus (130 mm) & $0.18(0.005)$ & $0.38(0.5)$ & $0.02(0.002)$ & $0.038(0.002)$ & 90 & $31.3(13.3)$ & $69.1(8.9)$ & $0.7(0.3)$ \\
\hline Maja squinado (120 mm) & 0.12 & $0.17(0.02)$ & $0.12(0.02)$ & $0.15(0.01)$ & 25 & NA & $20(3.2)$ & 0 \\
\hline Hyas araneus $(80 \mathrm{~mm})$ & 0.0987 & $0.12(0.009)$ & $0.105(0.01)$ & $0.13(0.02)$ & 23 & $\mathrm{NA}$ & $25(4.1)$ & $4(2)$ \\
\hline Homalaspis plana $(130 \mathrm{~mm})$ & $0.11(0.004)$ & $0.18(0.04)$ & $0.021(0.002)$ & $0.031(0.003)$ & 47 & $13.25(1.75)$ & $63(3.2)$ & $10.2(1.5)$ \\
\hline Ovalipes trimaculatus $(90 \mathrm{~mm})$ & $0.16(0.01)$ & $0.085(0.004)$ & $0.035(0.01)$ & $0.076(0.006)$ & 117 & $8.94(1.13)$ & $50.6(5.5)$ & $1.1(0.87)$ \\
\hline Carcinus maenas $(80 \mathrm{~mm})$ & 0.056 & $0.09(0.01)$ & $0.32(0.02)$ & $0.46(0.05)$ & 43 & NA & $30(8.2)$ & $6(1.7)$ \\
\hline
\end{tabular}


to the brood among Brachyuran crabs. Evidence for the patterns of oxygen provision to the embryos and the role played by brooding females are quite solid, since they are based on more than seven species.

The patterns of oxygen availability are remarkably similar across species, even considering species that remain buried while brooding, such as $O$. trimaculatus. Clearly, all species show cycles of oxygen provision to the embryos during early development in the center of the embryo mass (Fig. 1) and constant and high oxygen concentration during late development (Fernández et al. 2000, 2002, 2003, Baeza \& Fernández 2002, Fernández \& Pörtner unpublished results, this study). Oxygen availability at the periphery of the embryo mass remained high throughout development in all species (Fig.1).

The difference in oxygen availability in the center of the embryo mass between early and late developmental stages has an important effect on the total time that the embryos are exposed to different oxygen conditions throughout development (Fernández et al. 2000, 2002, 2003, Baeza \& Fernández 2002). Crab embryos are exposed between 20 and $70 \%$ of the time at low oxygen partial pressures in early stages of development, and less than $15 \%$ during late development (Table $1)$. The low levels of oxygen availability in the center of the embryo mass of females carrying early stage embryos seem to affect embryo developmental rate (Fernández et al. 2000, 2003).

Among the behaviors that were studied in brooding females, only one was positively correlated with increases in oxygen availability in the embryo mass: abdominal flapping. The standing position probably improves the effect of flapping, since the abdomen is gently lifted from the substrate each time females exhibited this behavior. In contrast to abdominal flapping, maxilliped beating, and pereiopod and chela probing were rarely observed to increase the oxygen availability in the center of the brood masses. We think that they may be used to assess oxygen conditions in the embryo mass. The high concentration of chemosensory setae in these appendages are probably involved in the detection of compounds produced by the embryos when subjected to low oxygen availability, producing female response (Ache 1982, Altner et al. 1982, Schmidt \& Gnatzy 1984).

The direct link between oxygen availability and the presence of one or more abdominal flapping was analysed in three species (Baeza \& Fernández 2002, Brante et al. in press, Fernández et al. 2003), although the effect of abdominal flapping on oxygen supply was indirectly assessed in sev- eral other crab species (Fernández et al. 2000). The increase in the frequency of abdominal flapping with embryo development seems to be related to the oxygen consumption rate of the embryos (Fernández et al. 2002). The effect of the oxygen consumption of the embryos on the frequency of abdominal flapping was also observed in experiments conducted at different temperatures (Brante et al. 2003). We think that abdominal flapping is triggered by (1) low oxygen partial pressure and (2) a waterborne substance produced by the embryos (Fernández et al. 2002), which concentrations vary throughout development.

It is important to note that most evidence points to the role of abdominal flapping as the key behavior used to provide oxygen to the embryos, regardless of the habitat. The relationship between abdominal flapping frequency and oxygen availability in the embryo mass was found in crab species that shelter in rocky areas (Fernández et al. 2000, 2002, Baeza \& Fernández 2002), inhabit sandy habitats or live buried in mud (e.g., Ovalipes trimaculatus). However, among-species comparison showed that different frequencies of abdominal flapping generate similar oxygen conditions in the center of the embryo mass of the species studied so far. The two-fold increase in the frequency of abdominal flapping between females of $O$. trimaculatus carrying early and late stage embryos is lower than that found in other crab species (almost a 10-fold increase in Cancer setosus, Baeza \& Fernández 2002, and Homalaspis plana, Fernández et al. 2002). We think that the rate of increase in the frequency of abdominal flapping between females carrying early and late stage embryos is related to the increase in oxygen consumption of the embryos throughout development. Ovalipes trimaculatus and other swimming crab species show a low rate of increase in oxygen consumption of the embryos (27\%) compared to other Brachyuran crabs (>200\% in Cancridae, Xanthidae, and Majidae; Fernández \& Pörtner unpublished results). Interestingly, the mean total time that the embryos of $O$. trimaculatus were exposed to low (and high) oxygen partial pressure in the center of the embryo mass during early development did not differ from estimates reported for other crab species (Table 1).

It is also important to mention that the frequency of abdominal flapping does not vary between day and night (nor, during early or late development; Ruiz-Tagle et al. 2002) in spite of that other crab behaviors do follow a clear daily pattern (Brown et al. 1954, Arudpragasam \& Naylor 1964, Palmer 1973, 1995, Naylor et al. 1997). This suggests that oxygen supply must be 
such a critical factor for embryo development that female crabs can not abandon this activity even when other activities are not performed. The rate of food intake of brooding females decreases as embryo develop, suggesting also that females concentrate more time and effort on supplying oxygen to the embryos.

\section{THE CONSEQUENCES OF ACTIVE OXYGEN PROVI- SION: COST OF REPRODUCTION AND THE EFFECT ON EGG PRODUCTION}

The involvement of female crabs in embryo ventilation is obvious, and clearly indicates that oxygen provision to the brood is a form of maternal care in Brachyuran crabs. It also suggests that such an involvement may have some costs associated. In fact, recent studies on Brachyuran crabs have shown that ovigerous female crabs consume a substantially higher amount of oxygen than non-brooding females (Fernández et al. 2000, Baeza \& Fernández 2002, Brante et al. 2003). Actually, brooding female crabs double their oxygen consumption rates, regardless of whether they bury in mud, or inhabit sandy or rocky substrates. The oxygen consumption rate of brooding females increases with temperature with respect to non-brooding females, probably due to the increase in the frequency of abdominal flapping, which in turn seems to be related to oxygen consumption of the embryos (Brante et al. 2003). This higher rate of oxygen consumption is not compensated by a higher rate of food intake, since food consumption of female crab decreases during the brooding period (Ruiz-Tagle et al. 2002). There is some evidence that maternal effort (e.g., addition of gel as extraembryonic material) in other species of marine invertebrates may also be driven by oxygen limitations in the embryo mass (Lee \& Strathmann 1998). Investment in extraembryonic material may reach up to $50 \%$ of the total energy investment in reproductive structures, including eggs (Lee \& Strathmann 1998). Moreover, gel addition per embryo seems to increase with the size of the embryo mass (Lee \& Strathmann 1998), which correlates with female size. This information on gelatinous embryo mass suggests that female size may affect investment in oxygen supply (either active or passive) to the embryos. This evidence is not trivial, since body size seems to be a major factor determining modes of development (Strathmann \& Strathmann 1982).

The consequences of investment in oxygen supply, either passively or actively, on subsequent growth, survival, and future reproduction are still unknown. However, some evidence suggest that investment in eggs, and clutch size determination, are not independent from the problem of oxygen limitation during early development. Comparisons of maternal effort, separating investment in eggs and in embryo ventilation at three temperatures along the coast of Chile showed that investment in eggs increased as investment in ventilation of the embryos decreased (Brante et al. 2003). This does not indicate that female produce more eggs at high latitudes, but that investment in eggs is higher. Females may invest more energy per egg, and still produce the same number of eggs. This result suggests that there may be a trade-off between investment in eggs and in ventilation of the embryos. Moreover, it suggests that investment in eggs must be constrained by the cost of ventilation rather than by limitation in space available for yolk accumulation in the carapace, as suggested by Hines $(1982,1986)$. The hypothesis that oxygen availability limits egg production, or determines clutch size, in brooding species is also supported by data the gastropod Acanthina monodon (Lardies \& Fernández 2002). It has been found that oxygen partial pressure determines the ratio between nurse eggs and embryos in this species: more embryos develop as oxygen partial pressure increases (Lardies \& Fernández 2002).

The decrease in the cost of oxygen provision as temperature decreases in Brachyuran crabs can be explained by (1) differences in oxygen solubility and (2) differences in oxygen consumption rate of the embryos. Similar results are not available for other groups of marine invertebrates. However, if this pattern holds for other groups of marine invertebrates exhibiting contrasting modes of development, and the benefits of aggregating eggs are large (e.g., increased survival), higher frequency of brooding species should be expected in cold waters simply by differential costs of brooding. An increase in the frequency of brooding species has been reported for marine invertebrates (Thorson 1950, Gallardo and Penchazadeh 2001 for the coast of Chile, Poulin et al. 2002).

\section{CONCLUSIONS AND FUTURE DIRECTIONS}

The information presented above supports the need for including the cost of oxygen provision in the estimation of maternal effort. However, currently investment in reproduction in marine invertebrates is estimated by the weight of the gonad, eggs, or embryos (Browne \& Russell-Hunter 1978, Hughes \& Roberts 1980, Hines 1982, Havenhand \& Todd 1989, Grant 1990, Todd 1990, Willows 1990, Brey 1995, Coma et al 1995, Wil- 
son-Ormond et al. 1995). The limited approach to the study of reproduction in marine organisms may have affected our understanding of the critical factors affecting the evolution of patterns of development in the ocean, especially considering the enormous variety of modes of development observed. The relationship between developmental mode and maternal effort remains poorly understood and new research in this area may lead to new insights into patterns of life history evolution of marine invertebrates. Research on the role of oxygen provision to the brood could play a critical role in this context, and a broad range of possible areas of research can be proposed to advance in this direction concentrating either on marine invertebrates in general, or Brachyuran crabs in particular. Firstly, latitudinal gradients in temperature, investment in eggs, and investment in oxygen provision. This could help to determine if brooding is costly in all groups of marine invertebrates, and if there are some environmental conditions (temperature and solubility of oxygen in seawater) under which the cost of brooding may be lower, and brooding strategies favored. Secondly, the effect of body size on brooding, in different groups of marine invertebrates. This approximation will help to elucidate the question of whether the capacity to brood is driven by oxygen limitation in embryo aggregations and increases with body size. Thirdly, patterns of oxygen availability, solutions to supply oxygen, and the cost of brooding need to be estimated in nature to assess if natural ventilation is possible and thus the cost associated may be diminished. Fourthly, other costs associated to brooding need to be estimated (subsequent survival, growth, future reproduction). Fifthly, the problem of oxygen limitation on the evolution of clutch size may also produce a conflict between parents and offspring over optimal clutch size (Lee \& Strathmann 1998, Lardies \& Fernández 2002); competition for oxygen among siblings may occur and affect clutch size. As yet, oxygen competition among sibling in marine invertebrates has not been shown despite that some species exhibit ideal conditions for such studies since the embryos are enclosed physically in the same structure throughout development. Sixthly, it is of particular interest among Brachyuran crabs to evaluate what constrains egg production: space available for yolk accumulation (Hines 1982, 1986 ) or the cost of embryo ventilation (Brante et al. 2003).

\section{ACKNOWLEDGMENTS}

We acknowledge financial support from FONDAP (O\&BM 3-Crustacean), the Volkswagen Foundation, the Humboldt Foundation, FONDAPFONDECYT (grant 1501-0001), and FONDECYT (grant 1020860). We thank Matthew Lee for his help editing the manuscript.

\section{LITERATURE CITED}

ACHE BW (1982) Chemoreception and thermoreception. In: Bliss DE (ed) The biology of Crustacea, Volume 3: 369-398. Academic Press, London, United Kingdom.

ALTNER I, H HATT \& H ALTNER (1983) Structural properties of bimodal chemo- and mechanosensitive setae on the pereiopod chelae of the crayfish, Austropotamobius torrentium. Cell and Tissue Research 228: 357-374.

ARUDPRAGASAM K \& E NAYLOR (1964) Gill ventilation volumes, oxygen consumption and respiratory rhythms in Carcinus maenas. Journal of Experimental Biology 41: 309-321.

BAEZA JA \& M FERNÁNDEZ (2002) Active brood care in Cancer setosus (Crustacea: Decapoda): the relationship between female behaviour, embryo oxygen consumption, and the cost of brooding. Functional Ecology 16: 241-251.

BOOTH D (1995) Oxygen availability and embryonic development in sand snail embryo masses. Journal of Experimental Biology 198: 241-247.

BRANTE A, M FERNÁNDEZ, L ECKERLE, F MARK, HO PÖRTNER \& W ARNTZ (2003) Reproductive investment in the crab, Cancer setosus, along a latitudinal cline: egg production, egg losses and egg ventilation. Marine Ecology Progress Series 251: 221 232.

BREY T (1995) Temperature and reproductive metabolism in macrobentic populations. Marine Ecology Progress Series 125: 87-93.

BROWN JL (1987) Helping and communal breeding in birds. Princeton University Press, Princeton, New Jersey, USA. 354 pp.

BROWN F, W BENNETT \& H WEBB (1954) Daily and tidal rhythms of $\mathrm{O}_{2}$-consumption in fiddler crabs. Journal of Cellular Composition and Physiology 44: 477-506.

BROWN RA \& WD RUSSELL-HUNTER (1978) Reproductive effort in molluscs. Oecologia 37: 23-27.

CHAFFEE C \& R STRATHMANN (1984) Constraints on eggs masses. I. Retarded development within thick embryo masses. Journal of Experimental Marine Biology and Ecology 84: 73-83.

CLUTTON-BROCK TH, SD ALBON \& FE GUINNESS (1981) Parental investment in male and female offspring in polygynous mammals. Nature 289: 487489.

COHEN C \& R STRATHMANN (1996) Embryos at the edge of tolerance: effects of environment and structure of embryo masses on supply of oxygen to embryos. Biological Bulletin 190: 8-15. 
COMA R, M ZABALA \& J GILI (1995) Sexual reproductive effort in the mediterranean gorgonian Paramuricea clavata. Marine Ecology Progress Series 117: 185-192.

CRISP DJ (1959) The rate of development of Balanus balanoides embryos in vitro. Journal of Animal Ecology 28: 119-132.

DIESEL (1989) Parental care in an unusual environment: Metopaulias depressus (Decapoda: Grapsidae), a crab that live in epiphytic bromeliads. Animal Behaviour 38: 561-575.

DIESEL R (1992a) Managing the offspring environment: brood care in the bromeliad crab, Metopaulias depressus. Behavioral Ecology and Sociobiology 30 : $125-134$

DIESEL R (1992b) Maternal care in the bromeliad crab, Metopaulias depressus: protection of larvae from predation by damselfly nymphus. Animal Behaviour 43: 803-812.

FERNÁNDEZ M, C BOCK \& H-O PÖRTNER (2000) The cost of being a caring mother: the ignored factor in the reproduction of marine invertebrates. Ecology Letters 3: 487-494.

FERNÁNDEZ M, LM PARDO \& A BAEZA (2002) Patterns of oxygen supply in embryo masses of Brachyuran crabs throughout development: the effect of oxygen availability and chemical cues in determining female brooding behavior. Marine Ecology Progress Series 245: 181-190.

FERNÁNDEZ M, N RUIZ-TAGLE, S CIFUENTES, H-O PÖRTNER \& W ARNTZ (2003) Oxygen dependent asynchrony of embryonic development in embryo masses of Brachyuran crabs. Marine Biology 142: $559-565$

GALLARDO CS \& PE PENCHASZADEH (2001) Hatching mode and latitude in marine gastropods: revisiting Thorson's paradigm in the southern hemisphere. Marine Biology 138: 547-552.

GRANT A (1990) Mode of development and reproductive effort in marine invertebrates: should there be any relationship? Functional Ecology 4: 128-130.

HAVENHAND JN \& CD TODD (1989) Reproductive effort of the nudibranch molluscs Adalaria proxima and Onchidoris muricata: an evaluation of techniques. Functional Ecology 3: 153-163.

HINES AH (1982) Allometric constraints and variables of reproductive effort in Brachyuran crabs. Marine $\mathrm{Bi}$ ology 69: 309-320.

HINES AH (1986) Larval patterns in the life histories of brachyuran crabs (Crustacea, Decapoda, Brachyura). Bulletin of Marine Science 39: 444-466.

HUGHES RN \& DJ ROBERTS (1980) Reproductive effort of Winkles (Littorina spp.) with contrasted methods of reproduction. Oecologia 47: 130-136.

LACK D (1968) Ecological adaptations for breeding in birds. Methuen \& Compnay, London, United Kingdom. Xx pp.

LARDIES MA \& M FERNÁNDEZ (2002) The effect of oxygen availability on clutch size determination: the case of Acathina monodon. Marine Ecology Progress Series 239: 139-146.
LEE CE \& RR STRATHMANN (1998) Scaling of gelatinous clutches: effects of siblings' competition for oxygen on clutch size and parental investment per offspring. American Naturalist 151: 293-310.

NAYLOR JK, E TAYLOR \& D BENNETT (1997) The oxygen uptake of ovigerous edible crabs (Cancer pagurus) (L) and their eggs. Marine Behavior and Physiology 30: 29-40.

NAYLOR JK, EW TAYLOR \& DB BENNETT (1999) Oxygen uptake of developing eggs of Cancer pagurus (Crustacea: Decapoda: Cancridae) and consequent behaviour of ovigerous females. Journal of the Marine Biological Association of the United of Kingdom 79: 305-315.

PALMER J (1973) Tidal Rhythms: the clock control of the rhythmic physiology of marine organisms. Biological Review 48: 377-418.

PALMER J (1995) The biological rhythms and clocks of intertidal animals. Oxford University Press, New York, New York, USA. Xx pp.

PATEL B \& D CRISP (1960) Rates of development of the embryos of several species of barnacles. Physiological Zoology 33: 667-680

PERRON FE \& GC CORPUZ (1982) Costs of parental care in the Gastropod Conus pennaceus: age specific changes and physical constraints. Oecologia (Berlin) 55: $319-324$

PERRON FE (1982) Inter and intraspecific patterns of reproductive effort in four species of cone shells (Conus spp.). Marine Biology 68: 161-167.

POULIN E, AT PALMA \& J-P FÉRAL (2002) Evolutionary versus ecological success in Antarctic benthic invertebrates. Trends in Ecology \& Evolution 17: 218-222

RUIZ-TAGLE N, H-O PÖRTNER \& M FERNÁNDEZ (2003) Full-time mothers: daily rhythms in brooding and non-brooding behaviors in Brachyuran crabs. Journal of Experimental Marine Biology and Ecology 276: 31-47.

SCHMIDT M \& W GNATZY (1984) Are the funnel-canal organs the "campaniform sensilla" of the shore crab Carcinus maenas (Decapoda, Crustacea)? II. Ultrastructure. Cell Tissue Research 237: 81-93.

SHINE R (1988) Parental care in reptiles. In: Gans C (ed) Biology of the Reptilia: 276-329. Alan Liss, New York, New York.

STRATHMANN R \& M STRATHMANN (1982) The relation between adult size and brooding in marine invertebrates. American Naturalist 119: 91-101.

STRATHMANN R \& M STRATHMANN (1995) Oxygen supply and limits on aggregation of embryos. Journal of the Marine Biological Association of the United of Kingdom 75: 413-428.

STRATHMANN RR \& C CHAFFEE (1984) Constraints on eggs masses. II. Effects of spacing size and number of eggs on ventilation of masses of embryos in jelly, adherent group, or thin-walled capsules. Journal of Experimental Marine Biology and Ecology 84: $85-93$

THIEL M (1999a) Duration of extended parental care in marine amphipods. Journal of Crustacean Biology 19: $60-71$ 
THIEL M (1999b) Extended parental care in marine amphipods II. Maternal protection of juveniles from predation. Journal of Experimental Marine Biology and Ecology 234: 235-253.

THORSON G (1950) Reproduction and larval ecology of marine bottom invertebrates. Biological Reviews 25: $1-45$.

TODD C (1990) Mode of development and reproductive effort in marine invertebrates: is there any relationship? Functional Ecology 4: 132-133.

WHEATLY MG (1981) The provision of oxygen to developing eggs by female shore crabs (Carcinus maenas). Journal of the Marine Biological Association of the United of Kingdom 61: 117-128.

Associate Editors: Patricio Ojeda and Luis Ebensperger Received October 7, 2002; accepted February 11, 2003
WILLOWS R (1990) Mode of development and reproductive effort in marine invertebrates: no relationship predicted by life-history theory? Functional Ecology 4: 130-132.

WILSON EO (1971) Insect societies. Belknap Press of Harvard University Press, Cambridge, Massachusetts. $548 \mathrm{pp}$.

WILSON-ORMOND E, S ELLIS \& E POWELL (1995) Mode of development and reproductive effort in marine invertebrates: no relationship predicted by lifehistory theory? Functional Ecology 4: 130-132.

ZEH DW \& RL SMITH (1985) Paternal investment by terrestrial arthropods. American Zoologist 25: 785805 . 